\title{
Causes of Environmental Degradation in the Coastal Areas of South West, Nigeria
}

\author{
Joy Oluwatomi Jiboye ${ }^{1 *}$, Christopher Ogolo Ikporukpo ${ }^{2}$, Charles Olufisayo Olatubara ${ }^{2}$ \\ ${ }^{1}$ Pan African University, Institute of Life and Earth Sciences (PAULESI), University of Ibadan, Ibadan, NIGERIA \\ 2 University of Ibadan, Ibadan, NIGERIA
}

*Corresponding Author: oluwatomijoy@gmail.com

Citation: Jiboye, J. O., Ikporukpo, C. O. and Olatubara, C. O. (2019). Causes of Environmental Degradation in the Coastal Areas of South West, Nigeria. European Journal of Sustainable Development Research, 3(2), em0079. https://doi.org/10.20897/ejosdr/3969

Published: March 3, 2019

\begin{abstract}
Environmental degradation is an increasing problem in many parts of the world and the type of ecology prevalent in an area plays a major factor that determines the extent of degradation. The study examines causes of environmental degradation in coastal areas of south west Nigeria. It was propelled by environmental challenges, and identified responsible factors in the study area. Environmental degradation is the major concept in this study and the DPSIR framework was used in understanding the concept. The study was carried out using primary and secondary sources of data collection. The main techniques for primary data collection were questionnaire survey and focus group discussions. Data were collected from one thousand, seven hundred and eighty-two $(1,782)$ sampled respondents who are coastal dwellers that are involved in economic activities within the coastal areas. The FGD was conducted in 54 settlements with a minimum of 10 discussants which constitute a mix of the elderly men and women in all the sampled communities. Secondary data were obtained from National Population Commission (2006). Data were analysed using descriptive and inferential statistics as well as cartographic method, and the information from the FGD were analysed using a thematic approach. The study shows that waves breaking along the coastline are the main explanatory factors responsible for coastal erosion (84.0\%). Flooding in the settlements where it occurs was mostly attributed to tidal rise/tidal waves (97.0\%). Tidal wave was believed to be the major cause of water hyacinth $(51.8 \%$ ). Pollution is caused by a mixed factor of over development of coastal areas, migration to coastal areas, population growth and increased tourism. Soil infertility is caused mainly by sea water infiltration into farmlands especially when farmlands are located too close to coast lines $(73 \%)$. Over development of the coastal area is mainly responsible for sand mining $(67.0 \%)$. The study concludes that environmental influence remains strong in the coastal environment. Therefore, concerted community efforts are needed to provide leadership and modalities for the management of environmental challenges in coastal communities. Fundamentally, official attention should be geared towards reducing the rate at which the environment becomes degraded in the coastal communities.
\end{abstract}

Keywords: environmental degradation, causes, coastal Areas, South west, Nigeria

\section{INTRODUCTION}

The world's population of nearly one billion in the year 1800 has grown to approximately 7.4 billion in the year 2015, and population projections suggest that the world population will fall somewhere between 7.5 and 10.5 billion by 2050, depending on changes in national level fertility and mortality rates (UNPD, 2009). Humans are an integral component of the ecosystems in which they live and on which they depend (Wilson, 2002). During the 
past five decades, humans have changed these ecosystems more swiftly and comprehensively than in any other comparable human period, largely to meet the requirements for food, water and raw materials of a growing population (MEA, 2005). Sala and Knowlton (2006) emphasized that humans are significantly changing the diversity of life on the earth, and most of these changes represent a loss of biodiversity which is crucial to our continued well-being and survival. There is also evidence of significant benefits of these changes in terms of economic development and well-being for some people (Barbier, 2007). More generally, human-induced or natural change alters the functioning of ecosystems (Halpern et al., 2008; Nias, 2013), and this in-turn brings about the decline in the quality of the environment otherwise known as degradation.

As indicated by the I=PAT equation, environmental impact (I) or degradation is caused by the combination of an already very large and increasing human population $(\mathrm{P})$, continually increasing economic growth or per capita affluence (A), and the application of resource depleting and polluting technology (T) (Chertow, 2001). One of the major causes of environmental degradation is human disturbance. Natural factors such as low tides, high tides and even climate change also contribute to the rate at which the environment becomes degraded The degree of the environmental impact varies with the cause, the habitat, and the plants and animals that inhabit it (Skye, 2004).

It is perhaps ironic that the problems of the coastal areas are derived from its usefulness and in particular from the settlement of humans on or near the coast. It is therefore important to define what we mean by coastal areas. The coast can be defined as both the coastal area and coastal land. "The coastal area" is defined as the ground region which is within ten kilometres from ground boundary. Coastal areas may include coastal floodplains, coastal forests called mangroves, marshes, and tide flats (coastal areas affected by the rise and fall of the tide), as well as beaches, dunes, and coral reefs. (Brian, 1998).

Nigeria has a total coastline of about $963 \mathrm{~km}$ in a west-east stretch from Lagos to Cross River with over 20 million people living along the coastal area. Currently, the Nigeria population of about 186 million significantly put it as the most populous black nation. The population accounts for $2.3 \%$ of the world's total population, with about $2 \%$ growth rate. About $20 \%$ of Nigeria's residents also live in one of the nine coastal states which have greater number of biodiversity resources (Nigeria Biodiversity and Tropical Forestry Assessment, 2008). Because of the large number of this population that lives below poverty line, there is increase in the pressure on the coastal resources.

The biggest threat to the coastal resources in Nigeria therefore, is poverty, through land base activities (Awosika et al., 2001); as the resources remain their main cheap sources of food and income. In Nigeria, as at 1997 there were 5,081 plants species, out of which $0.40 \%$ are threatened and $8.5 \%$ endangered; 22,090 animal species $(20,000$ being insects), $0.14 \%$ of which are threatened and $0.22 \%$ endangered and 1,498 species of microorganism. Given their biological, biochemical, medicinal, sociological, and economic as well as aesthetics value, mankind must ensure that these resources are adequately protected as essential component of the natural restoration process in the coastal environment (Okebukola, 2001). The current pace of environmental change in Nigeria prompted partly by degradation continues at an alarming proportion (Weller, 2005).

The close proximity of the southern part of Nigeria to the Atlantic Ocean together with the existing wind patterns and soil classes, bestows on Southern western Nigeria diverse ecological habitats. Ecological habitats that can be found around this area include the strand vegetation, mangrove vegetation, forest and deltaic swamp (Twumasi, 2006). Different ecosystems experience different types of degradation depending on the prevailing climatic conditions. The type of ecology prevalent in an area will be a major factor that determines the extent to which the area could be degraded.

Several studies have sought to understand the relationship between coastal communities and environmental degradation (see for example, IUCN, 2003; Onuoha, 2008; Akinwale, 2010; Udofia and Udom, 2011; Banerjee and Madhurima, 2013; Idawarni et al., 2015). However, perception of the explanatory factors responsible for environmental degradation generally has been neglected. The thrust of this study therefore, is to analyse the causes of environmental degradation in the coastal areas of south west, Nigeria and to achieve this aim, the study examined pattern of causes of environmental degradation and perception of the most significant environmental problem in the study area.

\section{STUDY AREA}

South western coastal area of Nigeria extends from Nigeria/Benin Republic border and terminates at the OndoEdo border (part of Niger-Delta Region). It lies approximately between latitude $6^{\circ} 10^{\prime}$ to $6^{\circ} 50^{\prime} \mathrm{N}$ and longitude $2^{\circ} 45^{\prime}$ to $6^{\circ} 09^{\prime} \mathrm{E}$ (see Figure 1). The study area cuts across three states (Lagos, Ogun and Ondo states) of the eight coastal states of Nigeria. It is about $324 \mathrm{~km}$ long which is $33.6 \%$ of the nation's coastline of $963 \mathrm{~km}$ (Folade, 2011). This is presented in Table 1. 
European Journal of Sustainable Development Research, 3(2), em0079

Table 1. Coastlines of Nigeria by States

\begin{tabular}{lcc}
\hline State & Length of coastline in $\mathbf{~ k m}$ & \% of Total Coastline \\
\hline Lagos & 171 & 17.76 \\
\hline Ogun & 69 & 7.17 \\
\hline Ondo & 84 & 8.72 \\
\hline Delta & 117 & 12.15 \\
\hline Bayelsa & 186 & 19.31 \\
\hline Rivers & 111 & 11.53 \\
\hline Akwalbom & 96 & 9.97 \\
\hline Cross rivers & 129 & 13.40 \\
\hline Total & 963 & 100 \\
\hline
\end{tabular}

Source: Folade, (2011)

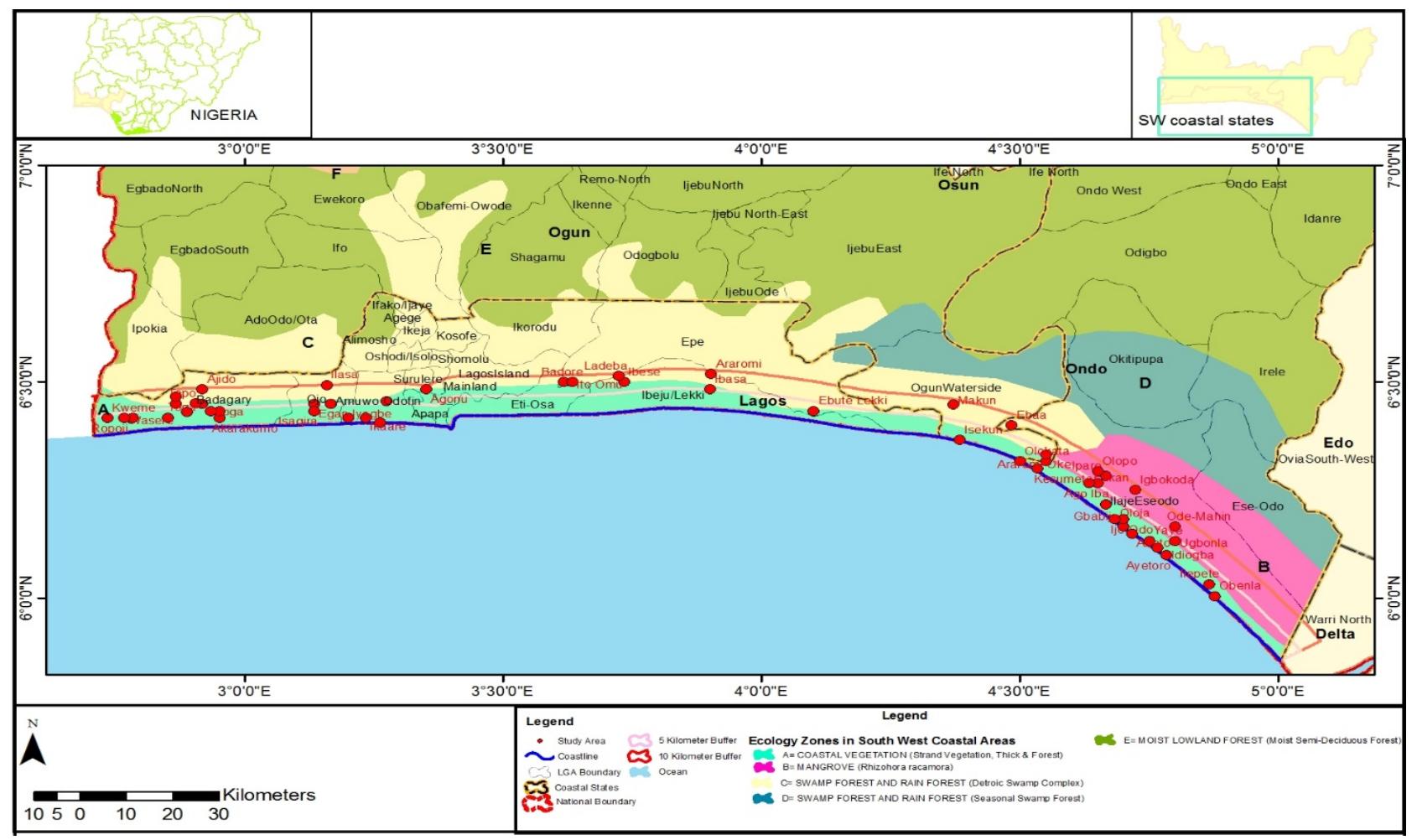

Figure 1. South West showing the Study Area

Source: The Author (2018)

The climate of the study area can be described as humid tropical. There are two distinct seasons, namely, the rainy season which lasts from March/April to 0ctober/ November and the dry season which lasts for the rest of the year, October/November till March/April.

Major geological formations include general alluvium, lagoonal marshes, abandoned beach ridges and coastal plains sand. The exposures on the general alluvium reveal coarse, clayey, unsorted sands with clay lenses and occasional pebble beds which are lithologically indistinguishable from typical coastal plains sand strata (Jones and Hockey, 1964).

In terms of the hydrology, the maze of creeks, rivers and lagoons which provide a cheap and in some localities the only means of transportation, constitute the most distinguishing physical feature of the coastal areas of the southwest Nigeria (Udo, 1970). They are the common hydrological features and form part of the numerous ecological niches associated with the Nigerian coastal environment (Chukwu and Nwankwo, 2004).

The south western coast is probably the most densely settled portion of the Nigerian coast with clusters of first-line settlements. The settlements in the study area are inhabited by indigenous people whose livelihood depends primarily on fishing and fisheries related activities as well as subsistence agricultural production (farming and farming related activities).

\section{CONCEPTUAL FRAMEWORK}

The United Nations International Strategy for Disaster Reduction characterizes environmental degradation as the lessening of the limit of the earth to meet social and environmental destinations, and needs (UNISDR, 2007). 


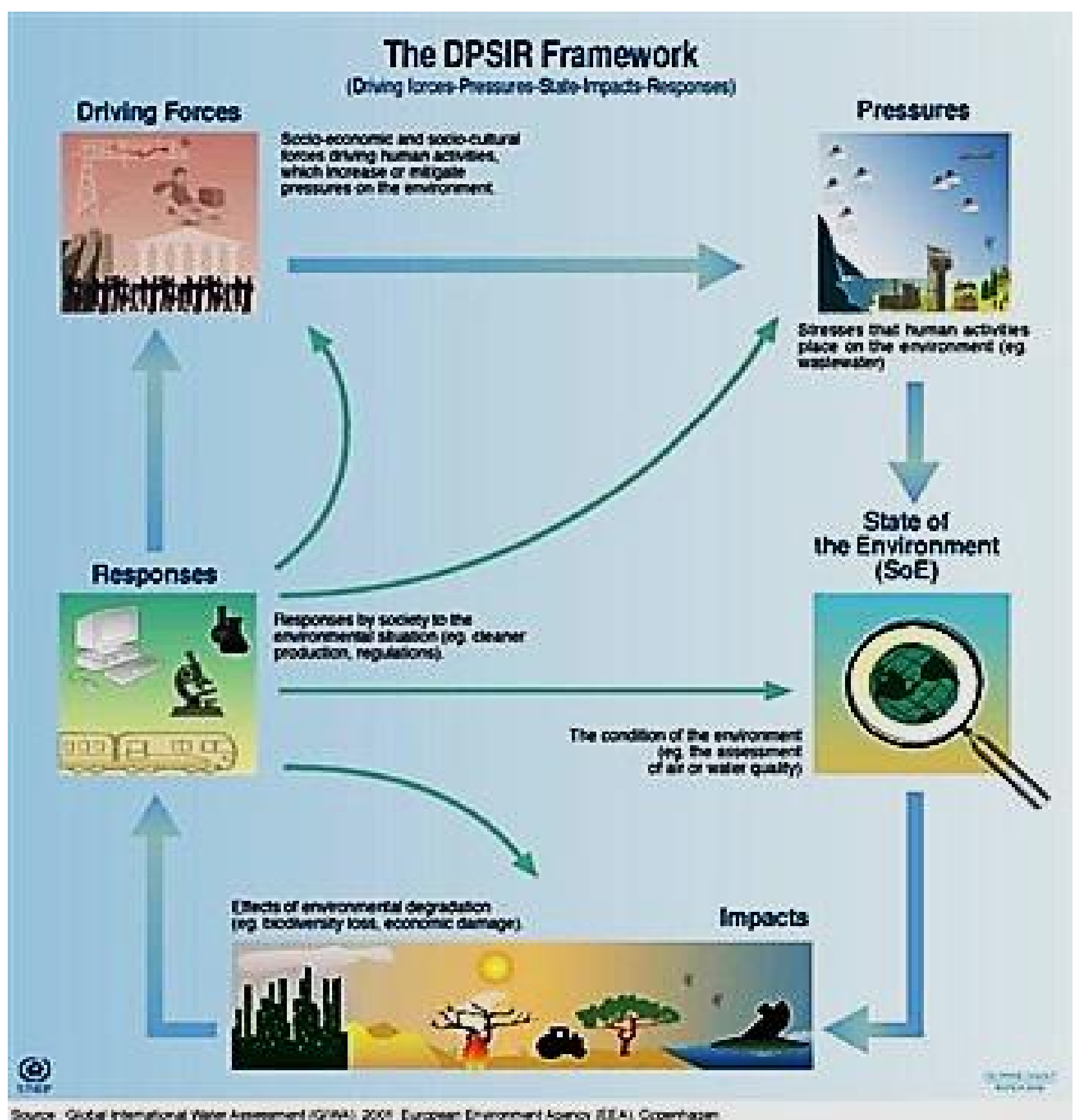

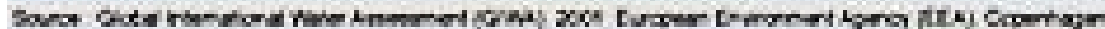

Figure 2. The DPSIR framework

Source: Global International Water Assessment (GIWA), 2001

According to Kukreja (2015) environmental degradation is the disintegration of the earth or deterioration of the environment through consumption of assets, for example, air, water and soil; the destruction of environments and the eradication of wildlife. It is characterized as any change or aggravation to nature's turf seen to be pernicious or undesirable. Ecological impact or degradation is created by the consolidation of an effectively substantial and expanding human populace, constantly expanding monetary development or per capita fortune and the application of asset exhausting and polluting technology. It occurs when earth's natural resources are depleted and environment is compromised in the form of extinction of species, pollution in air, water and soil, and rapid growth in population. Environmental degradation is also the deterioration in environmental quality from ambient concentrations of pollutants and other activities and processes such as improper land use and natural disasters (OECD, 2001).

In general, the environment provides all life support systems of every human society. These life support systems are built and sustained by the natural resources found in air, land and water. These resources include fresh/safe water, fish, arable land, plants, animals, mineral resources, air, among others. These resources often come in variable quantity and quality. Humans therefore exploit these resources for survival and sustenance. The misuse or over-use of these resources affects their quality and/or quantity in comparison with their pristine availability in 
the environment. Therefore, the issue of environmental degradation comes into play when these resources diminish in quantity or quality, or both. According to Jimoh (2006), environmental degradation refers to: the downward trend in the environmental resources such that their level of use in the human societies equally decreases at an increasing rate.

The European Environmental Agency (EEA), within the legal basis of the European Union Environmental Policy Acts 95, 174, 175 and 176 of the consolidated version of the Treaty on European Union and under the auspices of the European Commission, in their effort to introduce environmental issues in their developmental agenda, further improved the existing assessment frameworks into a five indicator framework (which includes PSR and DSR as special cases) dubbed as the "DPSIR assessment framework" (Jesinghaus, 1998; Pierce, 1998; EEA, 1999).

Each indicator conveys its own distinctive meaning and application. The framework is seen as giving a structure within which to present the indicators needed to enable feedback to policy makers on environmental quality and the resulting impact of the political choices made, or to be made in the future (Kristensen, 2004). "Driving forces" are social processes that cause either the increase or mitigation of pressures on the environment. Examples of such social processes are population growth, migration, poverty, level of production, human behaviours and attitudes and consumption pattern (Rigby et al., 2000). "Pressures" are represented by direct human activities on the environment, such as exploitation and excessive consumption of natural resources, beyond its carrying capacity, carbon dioxide emission into the environment, the use of fluorocarbons, use of mercury, lead, arsenic and cyanide in the purification and smelting of gold ores and the use of lead as an ingredient of gasoline (Rigby et al., 2000).

The "state" relates to the spatio-temporal changes to the environment that include rising global temperatures, ozone layer depletion, environmental degradation, soil erosion, soil compaction, desertification, deforestation, global warming, acidification and eutrophication. The "impacts" are the consequences of observed changes on the environment that include fall in agricultural production, per centage of children suffering from lead induced problems, food insecurity, malnutrition, mortality due to noise-induced heart attacks and number of people starving due to climate-change induced crop losses. The "responses" are what the society perceives to be done to realize a better environment and that include introduction of energy taxes, polluter pays principles, environmental conservation, environmental movement, environmental awareness programmes, environmental capacity building and mitigation measures (Pierce, 1998). The DPSIR assessment framework considers all the important indicators of environmental degradation assessment, hence its adoption in this study.

\section{LITERATURE REVIEW}

The causes of degradation remain controversial (Helene, 1991; Geist and Lambin, 2001). It's now thirty-seven (37) years after the United Nations Conference on Desertification (UNCOD) in 1977 which has gone and prompted an on-going and still unresolved debate about the causes and effects of degradation and desertification (Gary, 1999).

Environmental challenges are caused mainly by natural forces and human influences, or a combination of the two. Natural causes of environmental challenges include climatic, geologic, atmospheric, disease, and biological factors. Coenraads (2009) identified the major causes of natural disasters as geological events, meteorological incidents as well as biological disasters. According to him, geological events are triggered by the inherent working of our planet while meteorological events are caused by the variations in global weather patterns and biological events are caused by actions of living agents. Similarly, Petters (1995) submitted that while some natural disasters (e.g. volcanic eruption, earthquake and hurricane) arise from earth's inherent instability, others (e.g. mudflow, landslides and flood emanate from mass displacement of earth's materials. Likewise, Wright and Boorse (2011) accounted for the causes of natural hazards under the categories of hydrological, meteorological and geological forces. Anthropogenic challenges are caused mainly by human interference with the environment. Miller and Spolman (2009) identified population growth, wasteful and unsustainable resource use, poverty, as well as insufficient knowledge of how nature works as the major causes of environmental problems. In addition, Ofomata and Phil-Eze (2007) identified the poor application of the principles of environmental management as a major cause of some of the environmental challenges in Nigeria. Human activities like agriculture, fishing, livestock rearing and hunting are mounting pressures on the environment.

Furthermore, other activities like mining and exploration for petroleum, land reclamation, overfishing, overgrazing, deforestation, hunting, as well as the use of pesticides and herbicides are responsible for many environmental challenges. Many problems concerning environment and biosphere are simply there because so many people contribute little bits and pieces to it, all of which put together assume enormous dimensions (Asthana and Asthana, 2013:348). Madu (2007) submitted that the rapid growth in world population is a major cause of many environmental challenges. He noted that population size and rate of growth have led to the increase in the demand for food, clean water and energy increase. Consequently, the ability of the environment to meet some of 
these needs have become threatened. Moreover, poor people's reliance on natural resources, and the lack of alternatives to which to turn in times of stress have led to a high level of use which degrades the very asset on which their survival depends. For instance, road construction, timber harvesting, ranching, uncontrolled poaching and other human activities have led to the fragmentation of habitats and the subsequent disappearance of many species of flora and fauna. Other care-free attitudes of people towards the environment are urbanization and urban sprawl, industrialization, indiscriminate use of inorganic fertilizer, as well haphazard construction of buildings without regard to urban and regional planning laws and regulations. Dilys et al. (2011) opined that environmental challenges result from imbalances, corruption and inequality. All these give the poor little access to economic wealth of the nation, hence, their over-dependence on environmental resources. The vices are also responsible for environmental crimes like war, terrorist attack, arson, vandalism and other human aggressions towards the environment. These environmental crimes are aggravated by poverty and rapid increase in human population. Enger and Smith (2010) submitted that environmental problems occur as a result of the uncontrolled interaction between humans and the natural world. Inadequate monitoring of the environment has aggravated some challenges beyond their thresholds. For example, environmental challenges like flooding, pollution and erosion are caused mainly by poor drainage system, building along river channels, breakdown of dams and embankments, as well as poor urban planning. Also, deforestation and desert encroachment are caused by pressure on land, cultivation along slopes, overgrazing, shifting cultivation and other dangerous agricultural activities. From the foregoing, one could conclude that, the major causes of environmental challenges in Nigeria are natural forces, as well as uncontrolled human interference with the environment.

\section{MATERIALS AND METHODS}

The primary data used for this research was obtained from questionnaire surveys and Focus Group Discussions (FGD). A total of fifty-six (56) settlements were sampled from west to east along the coastline and between zero and ten kilometres away from the coast putting into consideration the ecological zones. The numbers of coastal settlements were acquired from a 2015 satellite imagery produced by Google Earth (with a resolution of about 15 $\mathrm{m}$ per pixel. This base imagery is $30 \mathrm{~m}$ multispectral Landsat which is pansharpened with the $15 \mathrm{~m}$ [panchromatic] Landsat imagery) and confirmed from existing maps of the study area and the names of the settlements were obtained from existing maps of the study area. Through ground trothing, the names and sites of these settlements were obtained and indexed appropriately. The coastal boundary shown on the imagery was digitized and over-laid with the existing administrative and ecological maps of the concerned states with the aid of ArcGIS. Also, the population data of all the localities of each state within the study area was obtained from the National Population Commission office of the respective states. The total population of this study is One hundred and fifty thousand, sixty two people $(150,062)$ (NPC, 2006). From this, a sample size of seven hundred and eighty-two $(1,782)$ was determined using Yamane (1967) sampling formula.

$$
n=\frac{N}{1+N(e)^{2}}
$$

$\mathrm{n}=$ sample size

$\mathrm{N}=$ Population size

$\mathrm{e}=$ margin of error (e) which is fixed at $2.35 \%$

Table 2 shows the selected communities across the study area, their population size and the number of questionnaires administered per settlement.

The Focus Group Discussions (FGD) was carried out among representatives of the elderly men and women in all the sampled communities. The elders provided, essentially, information on the explanatory factors responsible for environmental degradation, and also real/actual type of degradation prevalent in each of the settlements. This involved a discussion session with residents who had stayed in the area for a long period of time, and also those who were involved in the economic activities in the area. A digital tape recorder and a camera were used to capture the verbal and visual expressions of participants, which, along with the notes taken during the discussion, helped to transcribe the interviews. Also, some form of gratification was provided as incentives to appreciate each FGD group. Both descriptive (frequencies, per centages, charts) and inferential statistics (chi square tests) were used to analyse the data at $\mathrm{p}<$ or $=0.5$ level of significance as well as cartographical methods. 
European Journal of Sustainable Development Research, 3(2), em0079

Table 2. Population Size from Each Sampled Settlement

\begin{tabular}{|c|c|c|c|c|}
\hline $\mathrm{S} / \mathrm{N}$ & Settlement & Population & Population in $\%$ of total & Sampled population size \\
\hline 1. & Abalala & 1,189 & 0.8 & 14 \\
\hline 2. & Aboto & 5,017 & 3.3 & 59 \\
\hline 3. & Ago Iba & 2,112 & 1.4 & 25 \\
\hline 4. & Agonu & 290 & 0.2 & 4 \\
\hline 5. & Ajido & 3,357 & 2.2 & 39 \\
\hline 6. & Akarakumo & 575 & 0.4 & 7 \\
\hline 7. & Aradagun & 399 & 0.3 & 5 \\
\hline 8. & Araromi & 5,505 & 3.7 & 66 \\
\hline 9. & Araromi Obu & 592 & 0.4 & 7 \\
\hline 10. & Araromi Oke & 565 & 0.4 & 7 \\
\hline 11. & Ayetoro & 4,994 & 3.3 & 59 \\
\hline 12. & Badagry & 23,959 & 16.0 & 286 \\
\hline 13. & Badore & 501 & 0.3 & 5 \\
\hline 14. & Ebaa & 2,942 & 2.0 & 36 \\
\hline 15. & Ebute Lekki & 230 & 0.2 & 4 \\
\hline 16. & Egan & 279 & 0.2 & 4 \\
\hline 17. & Etikan & 1,474 & 1.0 & 18 \\
\hline 18. & Ganyingbo & 153 & 0.1 & 2 \\
\hline 19. & Gbabijo & 4,168 & 2.8 & 50 \\
\hline 20. & Ibasa & 376 & 0.3 & 5 \\
\hline 21. & Ibereko & 11,564 & 7.7 & 138 \\
\hline 22. & Ibese & 2,069 & 1.4 & 25 \\
\hline 23. & Idiogba & 5,544 & 3.7 & 66 \\
\hline 24. & Igbede & 3,621 & 2.4 & 43 \\
\hline 25. & Igbogbele & 712 & 0.5 & 9 \\
\hline 26. & Igbokoda & 4,918 & 3.3 & 59 \\
\hline 27. & Ijo Odo & 2,862 & 1.9 & 34 \\
\hline 28. & Ikare & 591 & 0.4 & 7 \\
\hline 29. & Ilasa & 1,808 & 1.2 & 21 \\
\hline 30. & Ilepete & 13,561 & 9.0 & 161 \\
\hline 31. & Ipare & 1,507 & 1.0 & 18 \\
\hline 32. & Isagira & 693 & 0.5 & 9 \\
\hline 33. & Isekun & 317 & 0.2 & 4 \\
\hline 34. & Ito Omu & 148 & 0.1 & 2 \\
\hline 35. & Itoga & 430 & 0.3 & 5 \\
\hline 36. & Iyafin Isalu & 503 & 0.3 & 5 \\
\hline 37. & Iyagbe & 781 & 0.5 & 9 \\
\hline 38. & Kesumetta & 322 & 0.2 & 4 \\
\hline 39. & Kweme & 717 & 0.5 & 9 \\
\hline 40. & Ladeba & 242 & 0.2 & 4 \\
\hline 41. & Makun & 1,658 & 1.1 & 20 \\
\hline 42. & Obe $\mathrm{Nla}$ & 4,918 & 3.3 & 59 \\
\hline 43. & Ode-Mahin & 5,429 & 3.6 & 64 \\
\hline 44. & Okun Ibese & 962 & 0.6 & 11 \\
\hline 45. & Oloja & 1,029 & 0.7 & 13 \\
\hline 46. & Olokata & 1,254 & 0.8 & 14 \\
\hline 47. & Olopo & 686 & 0.5 & 9 \\
\hline 48. & Olotu/Eruna & 1,400 & 0.9 & 16 \\
\hline 49. & Olute & 6,861 & 4.6 & 82 \\
\hline 50. & Panko & 131 & 0.1 & 2 \\
\hline 51. & Ropoji & 302 & 0.2 & 4 \\
\hline 52. & Topo & 3,750 & 2.5 & 45 \\
\hline 53. & Toga & 3,738 & 2.5 & 45 \\
\hline 54. & Ugbonla & 4,893 & 3.3 & 59 \\
\hline 55. & Wasere & 355 & 0.2 & 4 \\
\hline 56. & Yaye & 1,109 & 0.7 & 13 \\
\hline \multicolumn{2}{|c|}{ Total } & 150,062 & 100.0 & 1789 \\
\hline
\end{tabular}

Source: Settlement: Satellite Imagery Produced by Google Earth (2015)

2. Population (NPC, 2006).

3. Sample size calculated by the Author (2018) 


\section{RESULTS AND DISCUSSION}

\section{Pattern of Causes of Environmental Degradation}

\section{Coastal Erosion}

Figures 3 to 8 show different factors responsible for environmental problems in the study area. The factor that leads to coastal erosion in the study area as shown in Figure 3 is the strength of the waves breaking along the coastline. This submission is common in all the settlements where coastal erosion occured and it was given by about eighty four per cent (84\%) of the respondents. A wave's strength is controlled by its fetch and the wind speed. Longer fetches and stronger winds create bigger, more powerful waves that have more erosive power. Destructive practices of exploitation were also raised as a contributing factor by twelve per cent $(12 \%)$ of the respondents. Erosion caused by over development of coastal areas and over exploitation of coastal resources was therefore not common.

The discussants during the Focus Group Discussion said that coastal erosion is caused by a mix of factors, but tidal wave was also mentioned among the factors. In the words of Ayetoro discussants:

The coastal erosion is caused by so many things which include heavy rainfall, sea level rise, tidal waves action and so on that we lay men may not be able to explain (28/10/2016).

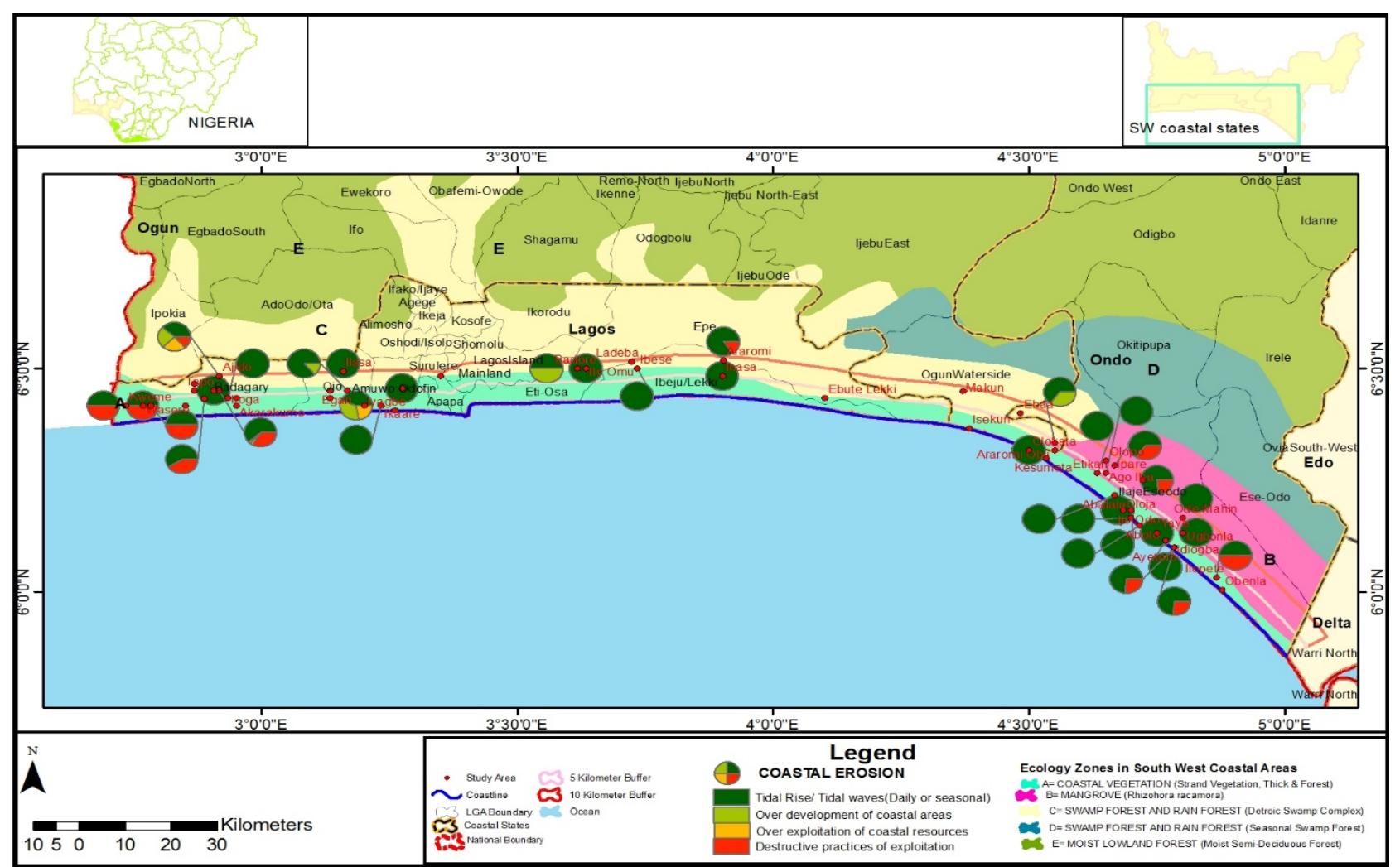

Figure 3. South West Showing Variation in the Causes of Coastal Erosion

Source: Author's Analysis (2018)

\section{Flooding}

In the study area, as indicated in Figure 4, flooding was mostly attributed to three factors which are Tidal Rise/Tidal waves (daily or seasonal), pollution/block drainages and climate change in the settlements where it occurs. Flooding was reported in about ninety three per cent $(92.9 \%)$ of the surveyed settlements with different intensity. Not all the communities shared the same opinion about the cause of flooding. For instance, Agonu, Egan, Ipare and Isagira respondents did not support the opinion that climate change leads to flooding. Also, the respondents within Kweme community were of the opinion that tidal waves lead to flooding. In general, thirty seven, thirty three and thirty per cent $(37 \%, 33 \%$ and $30 \%)$ of respondents in settlements where flooding is a menace attributed the cause to tidal waves, pollution/block drainages and climate change respectively.

From the view point of the discussants during the focus group discussion, flooding is also caused by a mix of factors which are heavy rainfall, blocked or no drainage, tidal waves and climate change. In the words of discussants in Ladeba community within Lagos state: 
Flooding occurs when there is heavy rainfall. And to worsen the case there are no well-constructed drainages. This makes water stagnant on the land. Stagnant water eats up the road. Also, due to climate change, rain may fall continuously for 5days, and this is always catastrophic (28/10/2016).

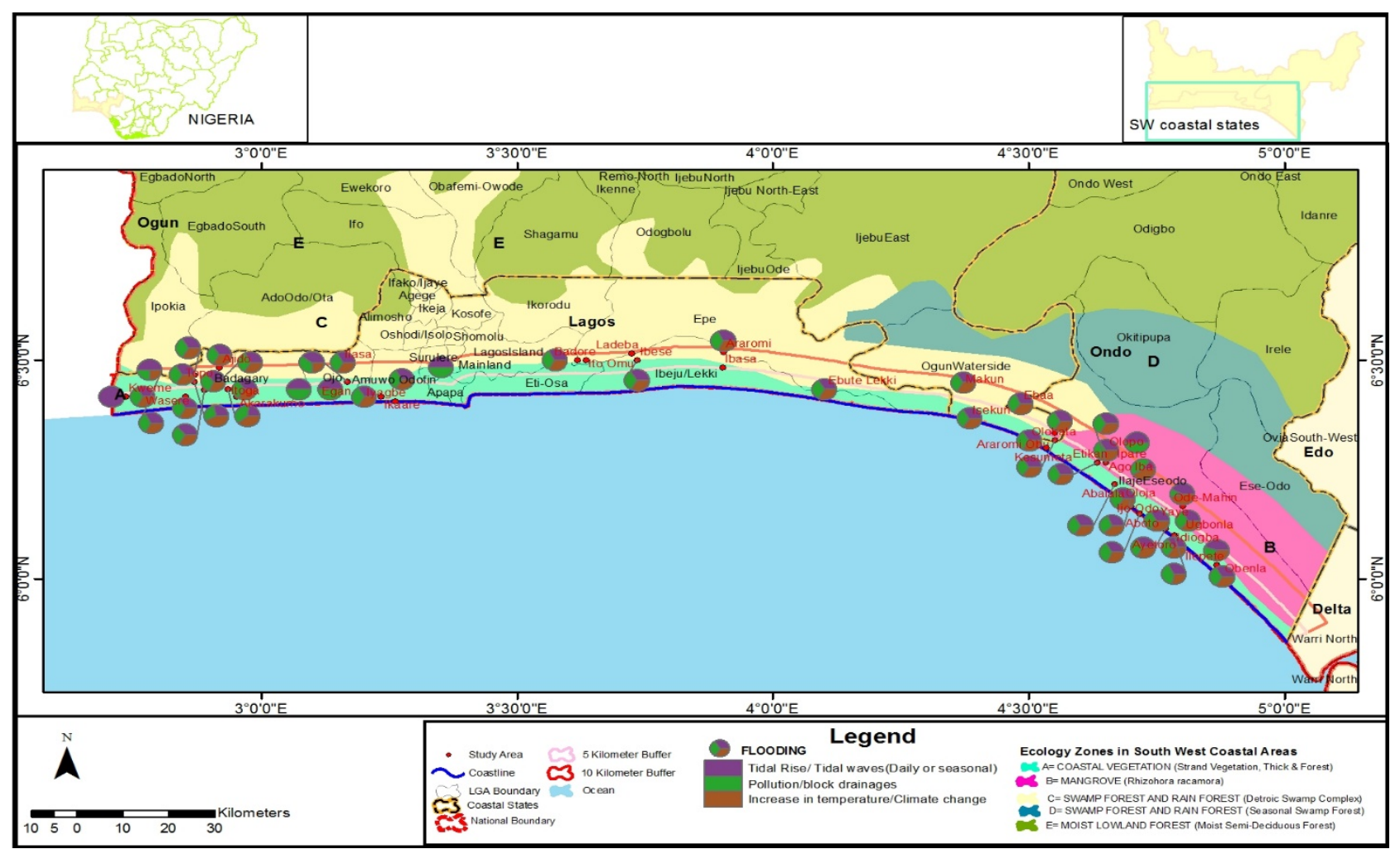

Figure 4. South West Showing Variation in the Causes of Flooding

Source: Author's Analysis (2018)

\section{Water Hyacinth}

Tidal wave was thus attributed as the major cause of water hyacinth in the study area (Figure 5).Water hyacinth was reported in about fifty two per cent $(51.8 \%)$ of the surveyed settlement and the perceived cause in all the settlement was the same and tends towards tidal waves. This is because water hyacinths are free floating and as the waves occur on water, they tend to move along with it. This opinion was given by ninety seven per cent $(97 \%)$ of the respondents in the settlements that reported water hyacinth as the most severe environmental problem. Only three per cent $(3 \%)$ of the respondents gave another opinion that the hyacinths were as a result of developments occurring in the coastal areas. Thus, the latter opinion was not a common one.

In the words of discussants at Makun Omi in Ogun state:

The water hyacinth started almost forty (40) years ago. We all thought it was a temporary thing. That maybe leaves were swept over the water, not knowing that it was not. If you take a good look at the hyacinths you will see that they have roots. This means they are growing plants. Their presence on water facilitates their growth. Water is their soil. So later on, we discovered that the hyacinths kept increasing day in day out. Thus as a community, we tried clearing them off manually. That time around 1990s, we bought fishing nets and started using it to clear off the hyacinths especially in the morning when they appear so much. After clearing, within some minutes, fresh ones flowed in. You know this Osa (Creek) is a long one that connects from Lagos down to this place also. So fresh hyacinths kept flowing in. so we gave up about clearing them. It was later that we learnt that the hyacinths flowed in from Benin republic through Lagos down to our own Makun-Omi community (27/10/2016).

Discussants in Isekun community also within Ogun state went on to specify the season the water hyacinths become most prominent on the water bodies.

At first the hyacinths were just in scanty patches on the water, but now it has become so much that it can cover $70 \%$ of the total surface especially during its season (May-September) (26/10/2016). 


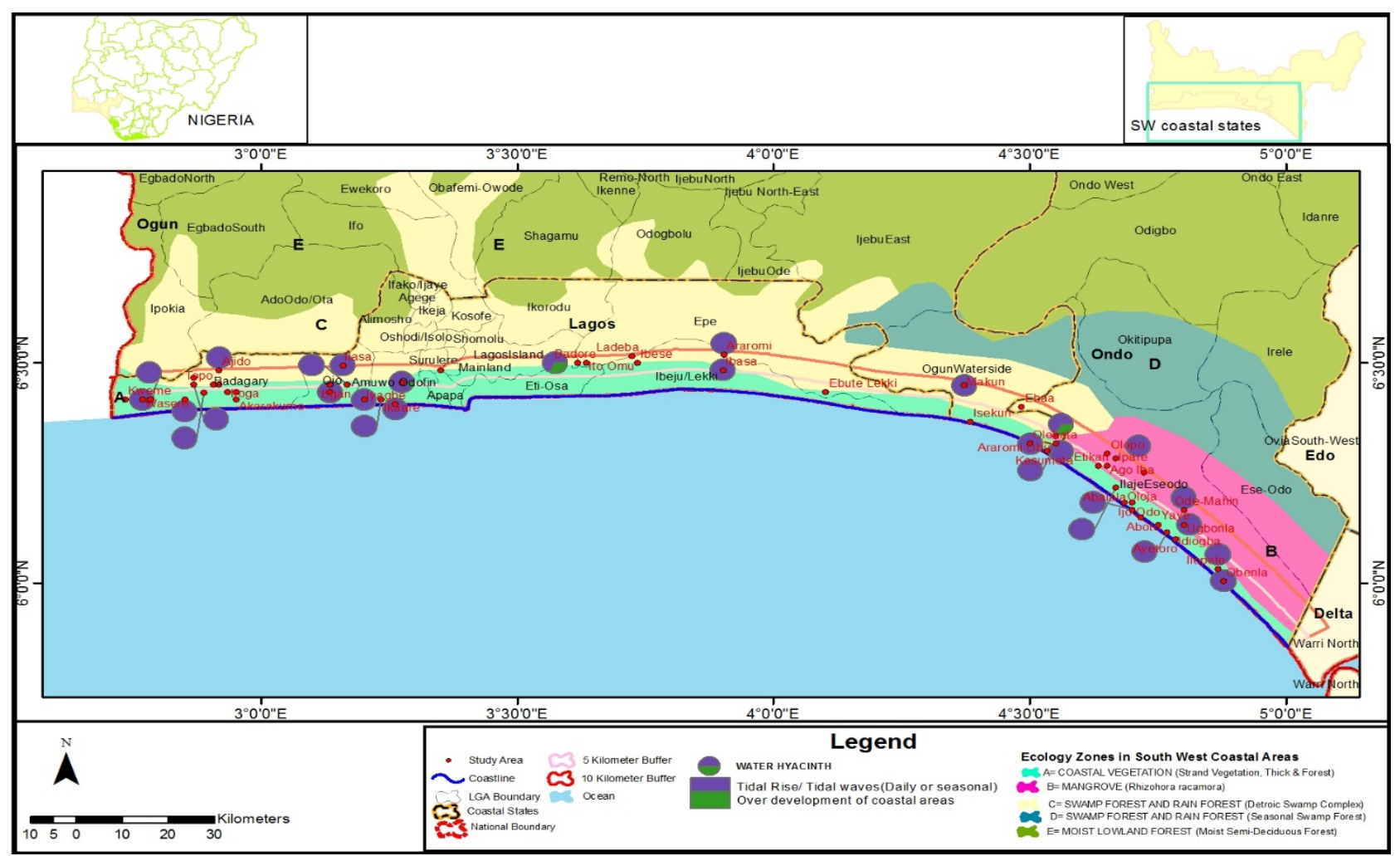

Figure 5. South West Showing Variation in the Causes of Water Hyacinth

Source: Author's Analysis (2018)

\section{Pollution}

Pollution as gathered from the survey is caused by a mixed factor of over development of coastal areas, migration to coastal areas, population growth and increased tourism (Figure 6). All these factors suggest that increase in human population caused either by tourism, urbanization or migration contributes to the menace of pollution. This mixed opinion was shared by respondents in all the settlements that indicated it as one of the environmental issues present in their communities. This pollution as observed by the researcher was both in form of land based pollution and sewage and organic pollution in water bodies. The only substance that is illegal to dump anywhere in the ocean is plastic. Plastics are primarily synthetic organic polymers derived from petroleum. Plastic materials are found to be the major macroscopic pollutants in most of the study area, and these plastics are being dumped into drainages and also on exposed soil ground where transportation agent of wind or water can easily move them into drainages.

Discussants within Ilase community in Lagos state opined that the sewage pollution was caused by the negligence of the government authority in clearing the dump sites. In their words:

Lagos State Waste Management Authority (LAWMA) has not been coming to this area to pack up refuse $(28 / 10 / 2016)$.

\section{Soil Infertility}

Soil infertility is the major environmental problem indicated by farmers in about forty three per cent $(42.9 \%)$ of the surveyed communities (Figure 7). Some of the farmers reported that tidal rise and fall contributes to soil infertility especially when farmlands are located too close to coast lines. This happens when the water brought in to the farm lands evaporates from the top soil and leaves the salt residue behind locked in the soil. Respondents in fifty per cent $(50 \%)$ of the communities (Araromi Obu, Ebaa, Ganyingbo, Gbabijo, Kweme, Okun Ibese, Olokata, Olopo, Ropoji, Toga, Ugbonla, Topo) had the opinion had only infiltration of ocean water into farmlands leads to soil infertility, while the other fifty per cent $50 \%$ shared the opinion that both tidal waves and sea water infiltration leads to soil infertility. Farmers among the discussants at Topo community explained the procedure further. In their words:

When sea water moves inland during high tides, they tend to remain stagnant on their farmlands in patches. Thus when the water eventually dries up, the salty impact of the sea water remains, and this makes the soil infertile. We end up using more and more fertilizers to reduce this impact. Also, soil seeps 
in water from the surrounding, and since the major water body here is salty, the soil also seeps in salty water.

In general, seventy three per cent $(73 \%)$ of the respondents suggested that soil infertility is caused by sea water infiltration while the remaining twenty seven per cent $(27 \%)$ indicated tidal waves as the cause.

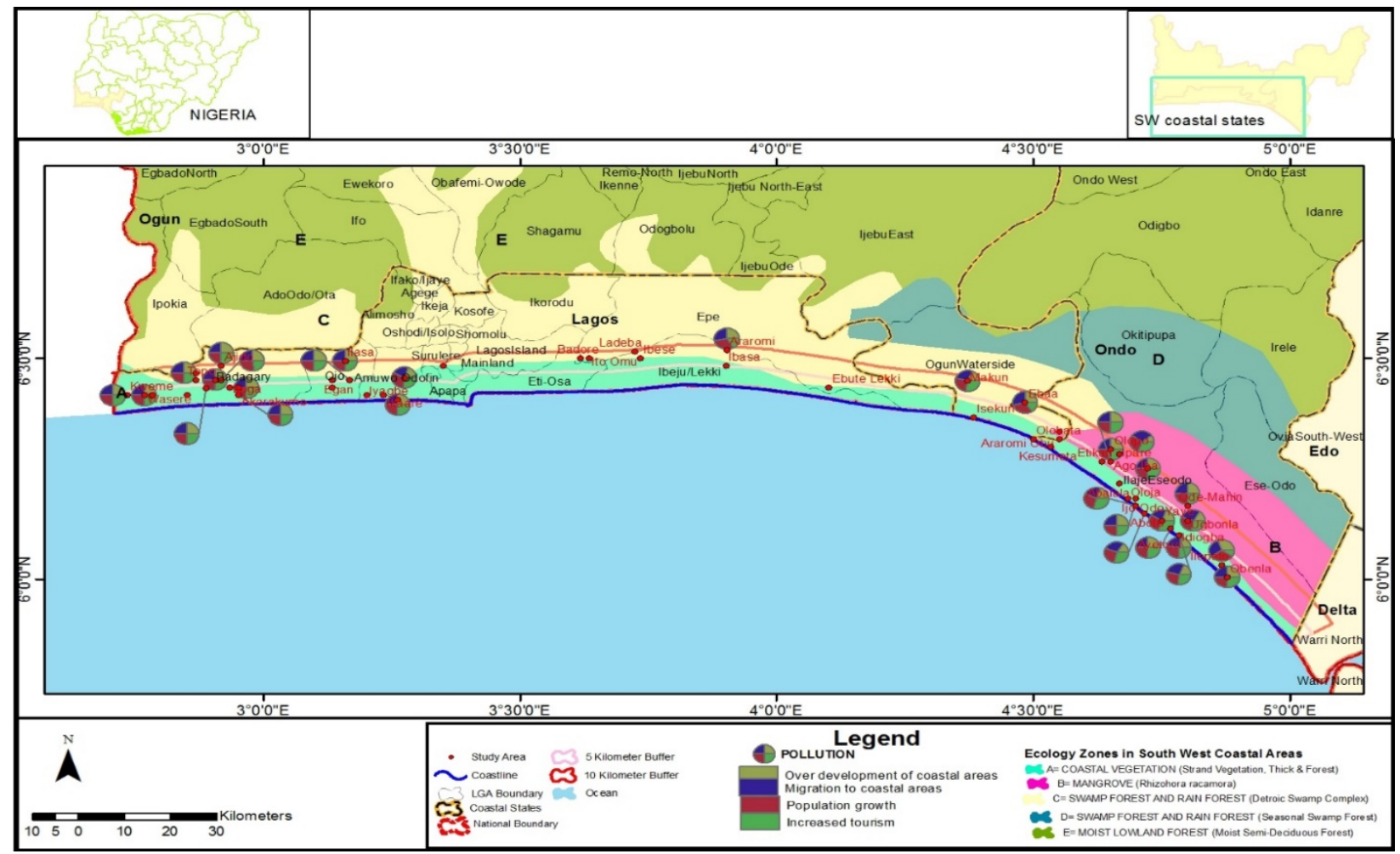

Figure 6. South West Showing Variation in the Causes of Pollution

Source: Author's Analysis (2018)

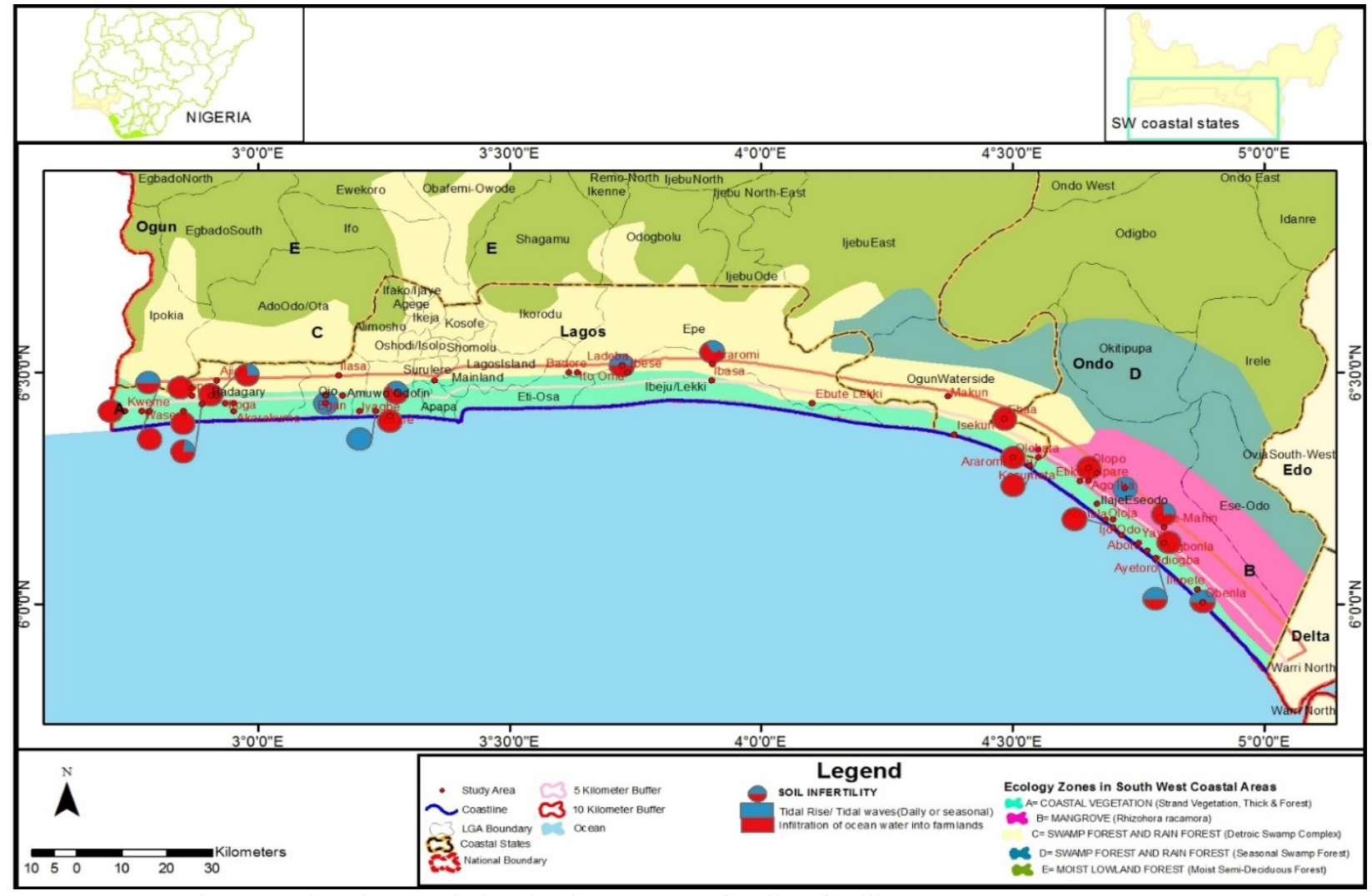

Figure 7. South West Showing Variation in the Causes of Soil Infertility

Source: Author's Analysis (2018) 


\section{Sand Mining}

From the survey, about sixty seven per cent $(67 \%)$ of the respondents whose livelihoods are being affected by sand mining opined that the cause is due to the over development of the coastal areas (Figure 8). This opinion was common among respondents in ninety six per cent $(96 \%)$ of the communities affected by sand mining. The request for sand for the purpose of road and housing constructions is high especially in the face of rapid urbanization. In the words of discussants in Abalala community sand mining, especially, excessive of it, is caused by lack of control regulations.

Most of the time, the sand miners put the sand together for sale. They sell to sand, gravel and granite sellers from which those that need it for construction will buy. So we can also say people mine more these days so as to meet with the increasing demand caused by development and population growth.

The effects of urbanization and the concentration of industrial and commercial activities along the coasts have resulted in an unprecedented exploitation of coastal resources such as coastal sand. The consequences are coastal flooding which is the most serious environmental problem facing the study area. Since coastal sand serves as a barrier between the sea and the land, uncontrolled sand mining causes a range of coastal environmental problems. Thus, the processes of degradation of the communities studied have intensified in recent times due to uncontrolled urbanization / over development of coastal areas.

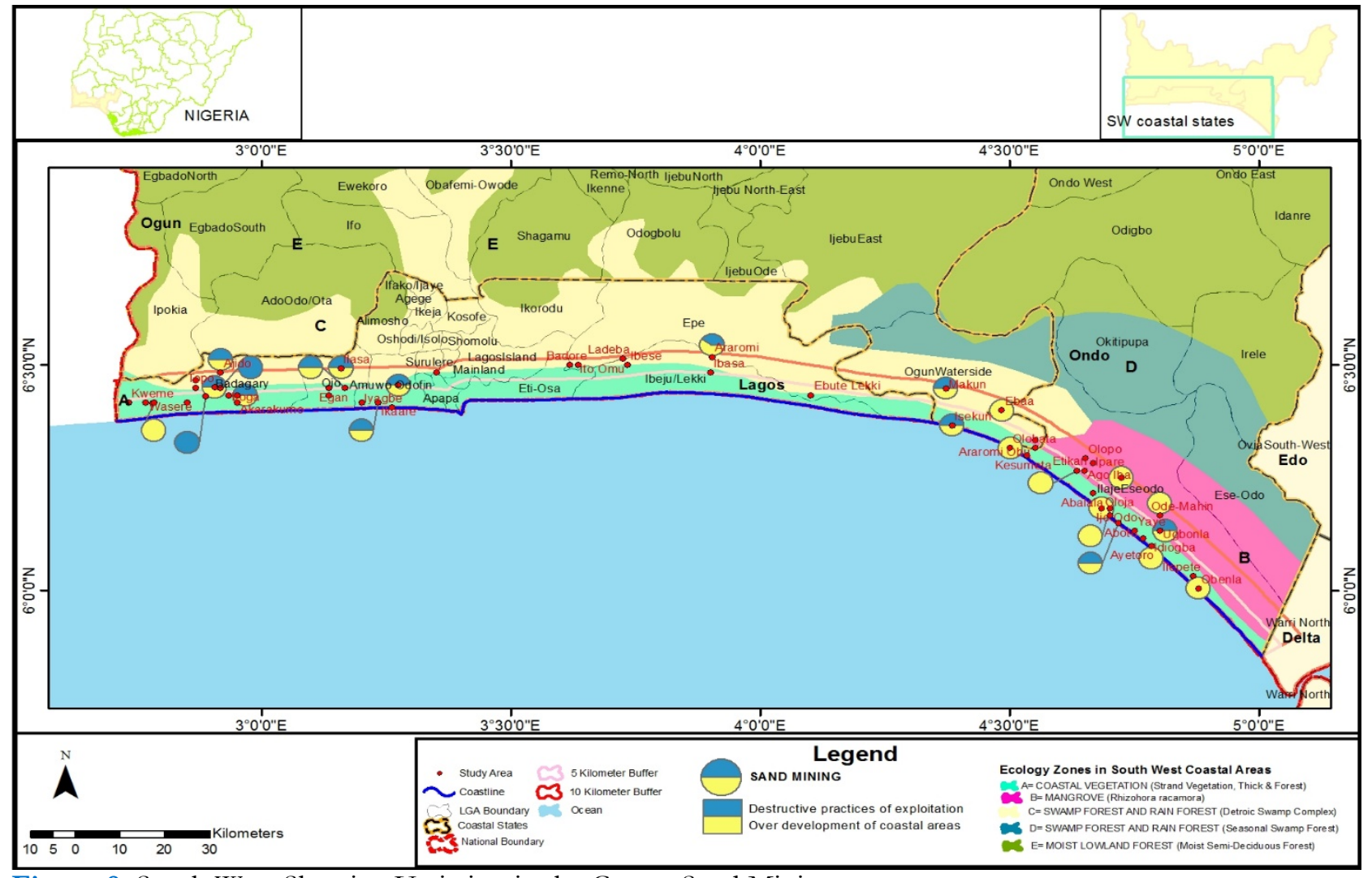

Figure 8. South West Showing Variation in the Causes Sand Mining

Source: Author's Analysis (2018)

\section{Variation in the Perceived Causes of Environmental Degradation over Space}

Table 3 shows significant variation in the perceived causes of different types of environmental degradation by locations separately. For coastal erosion, flooding, water hyacinth invasion and soil infertility, the variation is statistically significant $(\mathrm{p}<0.05)$. These results imply that perception of the residents regarding causes of coastal erosion; flooding, water hyacinth and soil infertility were not the same across the study area. However, perception of the causes of sand mining ( $p>0.05)$ and pollution $(\mathrm{p}>0.05)$ were the same across the settlements in the study area. The hypothesis which states that perception of the causes of environmental problems identified varies significantly over space is therefore accepted for coastal erosion, flooding, water hyacinth and soil infertility but rejected for sand mining and pollution. 
European Journal of Sustainable Development Research, 3(2), em0079

Table 3. Variations in the perceived causes of environmental degradation over space

\begin{tabular}{lcccc}
\hline Variables & $\boldsymbol{\chi}^{2}$ & $\mathbf{d f}$ & $\mathbf{p}$ & \multicolumn{1}{c}{ Decision } \\
\hline Coastal erosion & 91.190 & 55 & 0.002 & Sig. \\
\hline Flooding & 180.981 & 55 & 0.000 & Sig. \\
\hline Water hyacinth & 277.783 & 55 & 0.000 & Sig. \\
\hline Soil infertility & 135.661 & 55 & 0.000 & Sig. \\
\hline Sand mining & 39.873 & 55 & 0.938 & Not Sig. \\
\hline Pollution & 58.021 & 55 & 0.365 & Not Sig. \\
\hline Sort
\end{tabular}

Source: Author's Analysis (2018)

\section{Perceived Causes of Most Significant Environmental Problem}

As shown in Figure 9, about thirty three per cent $(33.3 \%)$ stated the flooding is caused by pollution and blockage of drainages by solid waste, another thirty three per cent $(32.9 \%)$ believed it is as a result of daily and seasonal tidal rise and tidal waves, while another thirty three per cent $(32.9 \%)$ were of the opinion that flooding is as a result of increase in temperature and climate change. Thus these three factors can be attributed as the major causes of flooding. Other factors contributing to flooding listed by respondents include migration to coastal areas, over exploitation of coastal resources, over development of coastal areas, destructive practices of exploitation and population growth. For coastal erosion, about seventy two per cent ( $72 \%$ ) (of the one hundred and fifty nine (159) respondents that indicated it as the most severe environmental problem), opined that it is caused mainly by daily and seasonal tidal rise and tidal waves, while another twenty $(20 \%)$ attributed the cause to destructive exploitation practices. Overdevelopment of coastal areas and over exploitation of coastal resources was among the reasons given.

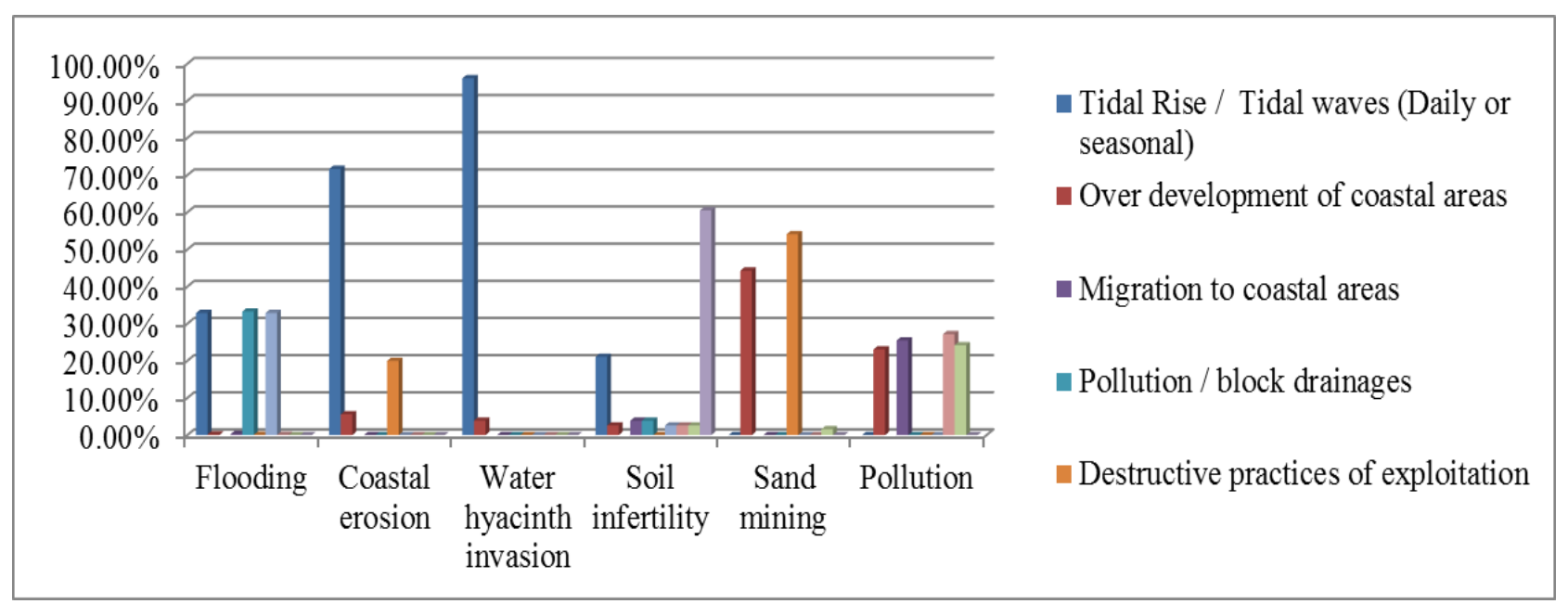

Figure 9. Perceived Causes of Most Significant Environmental Problem Source: Author's Analysis (2018)

Water hyacinth invasion was said to be caused by daily and seasonal tidal rise and tidal waves by ninety six per cent $(96.1 \%)$ of the one hundred and thirty nine (139) respondents that indicated it as the most severe environmental problem. Though from the Focus group discussions, how water hyacinth itself started was said to be unknown. But the influx of it was said to be caused by daily tidal waves. Infiltration of ocean water into farmland is the major factor that leads to soil infertility as indicated by about sixty one per cent (61\%) of the fifty four (54) respondents that indicated soil infertility as the main environmental challenge. Another twenty one per cent $(21.1 \%)$ indicated that soil infertility is also caused by daily and seasonal tidal rise and tidal waves. Sand mining was indicated as a destructive practice of exploitation by fifty four per cent $(54.1 \%)$ of the forty (40) respondents (mostly fishermen) that indicated it as the major environmental challenge facing them. Another forty four per cent $(44.3 \%)$ said sand mining is as a result of over development of coastal areas, that is the constant need for sand to be used in filling up water logged areas or for building construction is the main reason why sand need to be dredged from water bodies. Lastly, pollution was said to be caused by mixed factors which include population growth $(27.2 \%)$, migration $(25.5 \%)$, tourism $(24.2 \%)$ and then over development of coastal areas $(23.1 \%)$.

\section{Variation in the Perceived Causes of Most Significant Environmental Degradation over Space}

Table 4 reveals a significant difference in the perceived causes of most the most significant environmental degradation by location $\left(\chi^{2}=170.455 ; \mathrm{df}=30 ; \mathrm{p}<0.05\right)$. This indicates that perception of the explanatory factors 
responsible for the most significant environmental problems in the study area differs across the settlements in the study area. The hypothesis is therefore accepted.

Table 4. Variations in the perceived causes of environmental degradation over space

\begin{tabular}{llll}
\hline & Value & df & Asymptotic Significance (2-sided) \\
\hline Pearson Chi-Square & 170.455 & 30 & 0.000 \\
\hline Likelihood Ratio & 136.722 & 30 & 0.000 \\
\hline Linear-by-Linear Association & 2.589 & 1 & 0.108 \\
\hline N of Valid Cases & 1503 & \\
\hline a. 19 cells (45.2\%) have expected count less than 5. The minimum expected count is .03. \\
\hline Source: Author's Analysis (2018)
\end{tabular}

\section{CONCLUSION AND RECOMMENDATIONS}

Waves' breaking along the coastline is known to be the first factor responsible for coastal erosion across the study area. Flooding in the settlements where it occurs was mostly attributed to several factors such as tidal rise/tidal waves (daily or seasonal), pollution/block drainages, climate change, heavy rainfall and blocked or no drainage. Tidal wave was believed to be the major cause of water hyacinth in the study area. Pollution is caused by a mixed factor of over development of coastal areas, migration to coastal areas, population growth and increased tourism. Tidal rise and fall and infiltration of ocean water into farmlands are mainly responsible for soil infertility especially when farmlands are located too close to coast lines. This happens when the water brought in to the farm lands evaporates from the top soil and leaves the salt residue behind locked in the soil. Over development of the coastal area is mainly responsible for sand mining. Furthermore, perception of the causes of environmental degradation varies significantly over space. Daily and seasonal tidal rise and tidal waves arethe most severe environmental problems across the study area and the perceived causes of most environmental degradation differ significantly by locations.

Based on these findings, the study recommends that official attention should be geared towards reducing the rate at which the environment becomes degraded in the coastal communities. In addition, developmental projects and innovative measures for environmental protections should be provided. These innovative measures include features such as coastal defenses, groynes and levees. Essentially, good governance is central to improvement in the quality of the environment.

\section{REFERENCES}

Akinwale, A. A. (2010). Livelihood and environmental challenges in coastal communities of Nigeria. Journal of Sustainable Development in Africa, 12(8), 79-88.

Asthana, D. K. and Asthana, M. (2013). Environment: Problems and Solution (2nd ed.) New Delhi: S. Chand and Company Limited.

Awosika, L. F., Osuntogun, N. C., Oyewo, E. O. and Awobamise, A. (2001). Development and Protection of the Coastal and Marine Environment in Sub Sahara Africa: Report of the Nigeria Integrated Problem Analysis.

Banerjee, A. and Madhurima, C. (2013). Forest degradation and livelihood of local communities in India: A human rights approach. Journal of Horticulture and Forestry, 5(8), 122-129.

Barbier, E. B. (2007). Natural resources and economic development, Cambridge University Press.

Brian, D. K. (1998). Climate Change, Coral Reef Ecosystems, and Management Options for Marine Protected Areas. Springer Journal of Environmental Management, 44(6), 1069-1088.

Chertow, M. R. (2001). The IPAT equation and its variants. Journal of Industrial Ecology, 4, 13-29. DFID 1999 Sustainable Livelihoods Guidance Sheets.

Coenraads, R. (2009). Natural disasters and how we cope. Australia: Millennium House Pty Ltd.

Dilys, R., David, T., Jessica, S., Matt, W. and Joanna, E. (2011). Biodiversity and Poverty: Ten frequently asked questions Ten policy implications. London: International Institute of Environment and Development.

EEA. (1999). Environmental indicators: Typology and overview. Technical Report, 25, EEA. Copenhagen, Denmark.

Enger, E. D. and Smith, B. F. (2010). Environmental Science: A Study of interrelationships (12th ed.) Boston: McGrawHill.

Geist, H. J. and Lambin, E. F. (2001) What Drives Tropical Deforestation? A Meta-analysis of Proximate and Underlying Causes of Deforestation Based on Sub-national Case Study Evidence. Louvain-la-Neuve, Belgium: LUCC International Project Office. p. 116.

Global International Waters Assessment (GIWA). (2018). GIWA in brief. Available at: https://www.giwa.net (Accessed 16 July 2018) 
Halpern, B. S., Walbridge, S., Selkoe, K. A., Kappel, C. V., Micheli, F., D’Agrosa, C., Bruno, J. F., et al. (2008). A global map of human impact on marine ecosystems. Science, 319(5865), 948-952. https://doi.org/10.1126/science.1149345

Ibimilua, F. O. and Ibimilua, A. F. (2014). Environmental Challenges in Nigeria: Typology, Spatial Distribution, Repercussions and Way Forward. American International Journal of Social Science, 3(2).

Idawarni, A., Mukti, A. and Samsuddin, A. (2015). Coastal environmental degradation as communal space, Impact on social Fishermen community life at North Galesong. International Journal of Innovation and Research in Educational Sciences, 2(5), 2349-5219.

IUCN. (2003). Environmental degradation and livelihoods - Sea level rise'. Sindh Programme Office.

Jesinghaus, J. (1998). A European System of Environmental Pressure Indices. Introduction to the political and theoretical background. At: European Commission. DG34, Eurostat, Environment Statistics. Luxenbourg.

Jimoh, I. H. (2006). Pattern of environmental degradation and development efforts. Democracy and Development in Nigeria: Economic and Environmental Issues, 2.

Kristensen, P. (2004). The DPSIR Framework. Paper presented at the workshop on a comprehensive/detailed assessment of the vulnerability of water resources to environmental change in Africa using river basin approach. UNEP Headquarters, Nairobi, Kenya, 27-29 September 2004.

Kukreja, R. (2015). What is environmental degradation? Available at: Conserve Energy Future: http://www.conserveenergy-future.com

Madu, I. A. (2007). Population and environmental problems. In G. E. K. Ofomata and P. O. Phil-Eze (Eds.). Geographical perspectives on environmental problems and management in Nigeria (pp 80-95). Enugu. Jamoe Publisher.

Millenium Ecosystem Assessment (MEA). (2005). Millennium Ecosystem Assessment: Biodiversity Synthesis Report. Island Press, Washington DC.

Miller, G. T. and Spoolman, S. (2009). Introduction to Environmental science. Cengage Learning, New Delhi.

Nias, R. C. (2013). Endangered Ecosystems, in Levin, S.A. (Ed.). Encyclopaedia of Biodiversity (Second Edition), Academic Press, Waltham, pp. 169-175. https://doi.org/10.1016/B978-0-12-384719-5.00257-4

Ofomata, G. E. K. and Phil-Eze, P. O. (2007). Introduction. In G. E. K. Ofomata and P. O. Phil-Eze (Eds.), Geographical perspectives on environmental problems and management in Nigeria (pp. 1-10). Enugu: Jamoe Publishers.

Okebukola, P. (2001). Our Environment Our Destiny 2nd Distinguished Lectures Series AOCOED. On 1st March, 2001, Otto/Ijanikin Lagos.

Onuoha, F. C. (2008). Environmental degradation, livelibood and conflicts: A focus on the implications of the diminishing water resources of Lake Chad for North-Eastern Nigeria.

Petters, S. W. (1995). Natural and man-made hazards. In S. W. Peters et al. (Eds.) Environmental education. (pp. 134151) Lagos: Nigerian Conservation Foundation.

Pierce, M. (1998). Computer-based models in integrated environmental assessment. A report produced for the European Environmental Agency. Technical Report, 14, Copenhagen, Denmark.

Rigby, D., Howlett, D. and Woodhouse, P. (2000) Sustainability Indicators for Natural Resource Management and Policy Working Paper 1. A review of indicators of agricultural and rural livelibood sustainability. IDPM, University of Manchester, Manchester.

Sala, E. and Knowlton, N. (2006). Global marine biodiversity trends. Annual Review of Environment and Resources, 31(1), 93-122. https://doi.org/10.1146/annurev.energy.31.020105.100235

Twumasi, Y. A. (2006). GIS and Remote Sensing Applications in the Assessment of Change within a Coastal Environment in the Niger Delta Region of Nigeria.

Udofia, E. P. and Udom, E. S. (2011). The effects of environmental degradation on socio-economic condition in Iko community. Sacha Joumal of Environmental Studies, 1(2), 17-29.

UNISDR. (2007). Terminology. The United Nations Office for Disaster Risk Reduction. Available at: http://www.unisdr.org/we/inform/terminology (Accessed June 2012).

United Nations Development Programme (UNDP). (2009). Human Mobility and Development Report 2009, Palgrave Macmillan, New York.

Weller, K. (2005). Human Modification of the Nigerian Environment the University of Northern Iowa Geographic Alliance of Iowa, Cedar Falls Iowa background Information and study Areas on Nigeria.

Wilson, E. O. (2002). The Future of Life, Random House LLC.

Wright, R. T. and Boorse, D. F. (2011) Environmental Science: Toward a sustainable future Plus mastering environmental science with Access card package, 11/E Four categories of human environmental hazards. Available at: https://wps.prenhall.com/esm_wright_envisci11_oa 